\title{
A Quick Appraisal of the Impact of Environmental Changes on Undernutrition in Kenge Health Zone, DRC
}

\author{
Cush Ngonzo Luwesi ${ }^{1 *}$, Theophile Mbemba Di Luyundi ${ }^{2}$ \\ ${ }^{1}$ Associate Professor, Economics and Environment, Faculty of Economics, Kenge, DRC \\ ${ }^{2}$ Distinguished Professor, Biology and Environment, Faculty of Science, Kinshasa, DRC
}

*Corresponding author: Cush Ngonzo Luwesi, Associate Professor, Economics and Environment, Faculty of Economics, Kenge, DRC

\section{ARTICLE INFO}

Received: 豐 May 20, 2019

Published: May 28, 2019

Citation: Cush Ngonzo L, Theophile Mbemba Di L. A Quick Appraisal of the Impact of Environmental Changes on Undernutrition in Kenge Health Zone, DRC. Biomed J Sci \& Tech Res 18(3)2019. BJSTR. MS.ID.003145.

Keywords: Climate Change; Environmental Degradation; Ecological Rehabilitation; Land Cover; Land Use ; Undernutrition
ABSTRACT

The Democratic Republic of Congo (DRC) has undergone several structural changes in social behaviors, economics and health due to the burden of wars and the changing natural environment. Long known as the equatorial forest and food basket of the central African region, the country has been the theatre of wars and deforestation, which have affected the livelihoods of the people and led to incredible environmental degradation over the last 40 years. The country's national strategy for reducing undernourishment has encountered many challenges than anticipated, some of them being climatic and environmental by nature. Thus, in some rural areas, such as those around Kenge Municipality of the Kwango Province, undernutrition has become endemic, causing tremendous delays in child growth. This study unveils how deforestation has affected the food composition of some rural populations of the Kenge Health Zone in terms of biochemical nutrients change. It intends to assist policy makers and implementing agencies to provide sustainable solutions to the thorny issues of food shortage and endemic undernutrition through ecological rehabilitation.

\section{Significance of the Problem}

There is massive imbalance between Africa's capacity to feed its populations and the immense natural resources that the continent is endowed with [1-3]. The existing traditional food technologies for mitigating the impacts of undernutrition and hunger have encountered many challenges, owing to the drastic climatic changes and subsequent depletion of environmental resources, notwithstanding several structural changes in social behaviors, economics and health that have taken place since independence and those anticipated due to the burden of wars, population growth and migration [3-6]. Moreover, technologies used for climate change mitigation are based on market strategies that have often ignored the existing indigenous knowledge of the local communities and social inequities in the distribution of benefits accrue from natural resources, including food, water, energy, ecosystems and other environmental resources, bearing in mind that most of African livelihood generations are climate-dependent [6]. The diminishing natural reserves of food and energy coupled with the high cost of affording these resources have led to deforestation, social strikes and conflicts on the appropriation of natural resources, and further environmental harms [7]. Ultimately these harmful effects have heavily affected most African livelihood generations, thus leading to starvation, diseases and poverty. The limited capacity of policymakers and implementing agencies in addressing these problems have tremendously led to rapid and fundamental changes in the quality and quantity of food, water and energy, which further escalates conflicts of interest on appropriation of natural resources [8].

In addition, there is no enough observational data in the African continent to predict land-use and land-cover change (LULCC), to measure carbon emissions and to accurately forecast regional warming. Thus, most forecasting models leave out African countries in different scenario trajectories. Yet, from an African perspective, this omission is serious for policy-making and costly for the livelihoods of indigenous communities, including both rural and peri urban populations [9]. The African continent is one of the poorest continents in the world and at the same time the most vulnerable to climatic extreme events. Most Africans live poor resource livelihoods and are unable to cope with the physical, human and socioeconomic consequences of climate change (IPCC, 
2018). African policy makers and implementing agencies often point out to the global market-based mitigation policies which do not allow them to easily access certain forms of sustainable technologies, thus limiting their opportunities for sustainable solutions to climate change issues [6]. Yet, most developed countries have so far achieved significant technological improvement in the water, energy and environment sectors. Some of these advanced technologies have benefited some developing countries, leading to effective and efficient management and development of natural resources. There are thus immense demand pressures of these technologies in the African continent; however, their adoption is facing many challenges [6].

The DRC has undergone several structural changes in social behaviors, economics and health due to the burden of wars and its changing environment [10]. Long known as the equatorial forest and food basket of the central African region, the country has been the theatre of wars and deforestation, which have affected the livelihoods of the people and led to incredible environmental degradation over the last 40 years $[11,12]$. "That's often the case here in the DRC, the epicenter of what was called 'Africa's World War' (1998-2003), the deadliest conflict since World War II, and especially in the eastern reaches of the country where violence and terror have continued since the supposed end of that war Conflict and preventable disease continue to take the lives of tens of thousands each month-five years ago a fellow international organization here put the toll at over five million. The situation has little changed since then" [13]. In rural areas, such as those around Kenge Municipality, most people are poor and rely on natural resources for their livelihoods. Homesteads usually use firewood as their main source of energy for cooking. Additional firewood is used for making charcoal, which is an alternative source of energy. The demand for firewood has led to the clearing of forest in many parts of the Wamba sub-catchment of the Kwango River. Consequently, the ecosystem in which traditional food is found is seriously destroyed. The scarcity of forest resources justifies high prices of food and energy resources, following a widespread deforestation. This has caused severe threats to child health and growth, thus leading outrageous prevalence of child mortality due to malnourishment. Hence, undernutrition has become endemic, with more than $70 \%$ of children being vulnerable [14]. Chronic undernutrition claims millions of lives each year and is perhaps the most significant cause of diseases and deaths among children under 5 years, as well as the cause for physical and cognitive retardation in DRC. In fact, more than 6 million children are affected by pathologies that inhibit human physical and cognitive growth.

Eastern and lower Congo regions are the most affected, with rates ranging between $40 \%$ and 53\%. These include Eastern Province, Northern Kivu, Southern Kivu, Maniema, Katanga, Eastern and Western Kasai (about 53\%) as well as Central Kongo Province, Kwilu, Kwango and Equator (around 40\%) [15]. Unfortunately, policymakers have encountered many challenges than anticipated in implementing national strategies. If some challenges are economic and social by nature, others are climatic and environmental. So, what can be done to ensure sustainable solutions the thorny issues of endemic undernutrition among the under 5-year old, notwithstanding the economic burden of high food prices and low incomes in rural and peri-uban areas? This study provides a quick appraisal of the effects of environmental degradation on nutrition in order to set the stage for a deep inquiry for participatory natural resources management. It demonstrates how the biochemical composition of some foodstuffs are eroded by deforestation and thus resulting in some significant effects on food security, human nutrition and health [6]. The success of the measurements from the Kenge health zone may be up/out scaled to study other rural African regions and serve as a basis for shaping nutrition focused policy in the course of climate change.

\section{Proposed Solution}

The high prevalence of chronic undernutrition in almost all the provinces of DRC is certainly alarming. It does have a negative impact on the national income and human capital on which the country shall bank for its socio-economic development [16-18]. Several initiatives have thus been put in place by different actors to improve their community nutritional status and people's food security. In this context, the Government of the DRC has included nutrition amongst its priority areas in the national development policies and plans with the aim of reinforcing nutrition activities in order to contribute to the attainment of the Sustainable Development Goal (SDG) Number 2 that addresses food security and aims to eliminate hunger [19]. The national policy dealing with nutrition has thus been revised to demonstrate political will for achieving the SDG\#2. For the sake of clarity, the national policy on nutrition put an emphasis on a multisectoral approach towards solving undernutrition issue in a holistic way by reinforcing the synergy between various sectoral interventions [20]. A threeyear strategic action plan (SAP 2013-2015) has been adopted to promote infant's feeding and child nutrition so as to combat chronic undernutrition [21]. Among other operational goals, the SAP (2013-2015) aims at eliminating inadequate food technologies and practices to pave the way to a balanced and varied 4-star feeding model: Glucids-Lipids-Proteins-Vitamins. In this model, both the quality and quantity of the food designed are addressed along with the relevant steps for introducing these food items in the feeding process to counter undernourishment with respect to the four stars [22]. It is in such prospect that traditional food is being promoted as the most nutritious, affordable and accessible to rural and periurban communities. However, by raising the profile of traditional food in the national nutrition agenda, policymakers tend to neglect environmental protection, which is a key to ensuring sustainable food provision for nutrition and health among indigenous communities. Thus, protecting natural ecosystems against deforestation is likely to improve traditional food in quantity and quality, and increase food security so as to prevent undernutrition 
and child mortality in the DRC.

Di Luyundi (2013) provides exhaustive scientific information that highlights the importance of traditional food in the nutrition and health of indigenous communities. This inquiry presents the nutritional composition of different types of food, foodstuffs and other commodities commonly used in the Maindonde, Kwango and Kwilu provinces of DRC. Among such items, one can count edible caterpillars and insects, fish and wild meat, mushrooms, nutritious roots and tubers, as well as fruits, nuts and grains, to name but few items. In the Kwango province, the author enumerates over 16 types of insects, 18 grasshoppers, 3 types of larva, 23 caterpillars, 17 snakes, 22 birds, 22 fish species, 19 rats, 23 wild animals and 13 domestic animals, which are among the delicacies of the indigenous populations of the Kwango province. Since most of the ecosystems hosting traditional food baskets are being destroyed following widespread deforestation, these foodstuffs deplete progressively, and most of the peoples have over time resorted to alien cereals (i.e. maize, sorghum, millet), leguminous (peas, beans), vegetables (pumpkins, gumbo), fruits (pineapples, pawpaw, safu fruits) as well as meat and dairy products from abroad. These constitute supplementary food to the existing traditional food basket and help ensuring a balanced diet to local communities (Lodi, 2011). However, as the cost of acquiring these food items hikes, a majority of people cannot afford their cost. Hence, the need of protecting the ecosystems hosting traditional food baskets to allow these poor communities keep a balanced diet and enable their body functions harmoniously so as to maintain or increase the lifespan.

\section{Materials and Methods}

\section{Description of Study Area}

This study was conducted in the Kenge Health Zone of the newly delineated Province of Kwango [23-25]. The administrative census conducted by Ville de Kenge (2014) and projections by the DPSKwango (2018) indicate that this province covers an area of 89,458 $\mathrm{km} 2$ with a total population estimated to 2,504,824 inhabitants in 2014 and a density of 28 inhabitants. The Province of Kwango is limited to the north by the Wamba River and the Kikongo health zone; to the south by the Makiosi plain and the Kimbau health zone; to the east by the River Inzia and the Masi- Manimba health zone; to the West, by the Wamba River and Boko health zone. The national road No1 (Kinshasa-Kikwit), long of $275 \mathrm{~km}$, is the main channel of communication of the province. The Kenge health zone covers $5.559 \mathrm{Km} 2$ distributed between 28 health areas of 28 health centres each. With a population de 300,207 inhabitants and a density of 54 habitants/ $\mathrm{Km}^{2}$ this health zone is prone to malnutrition, 1 out of 2 children suffering from chronic undernutrition. Formerly known as the main granary of the Kinshasa capital city, the Province of Kwango has lost its huge potential for agricultural production which include a variety of food and rich cultures. Yet, the climate is tropical wet with two rainy seasons (September- January; and March-May) and two dry seasons (May to September; January-March). This partly explains the presence of the woodland savannah in the region. The city of Kenge entirely lies on plateaus intersected by valleys, and sometimes, hills between the rivers Wamba to the west and Bakili to the east. The soil is sandy of Karoo-Kalahari type. Its vegetation consists essentially of grassy savannahs, woodlands and forest galleries found along the rivers (Figure 1).

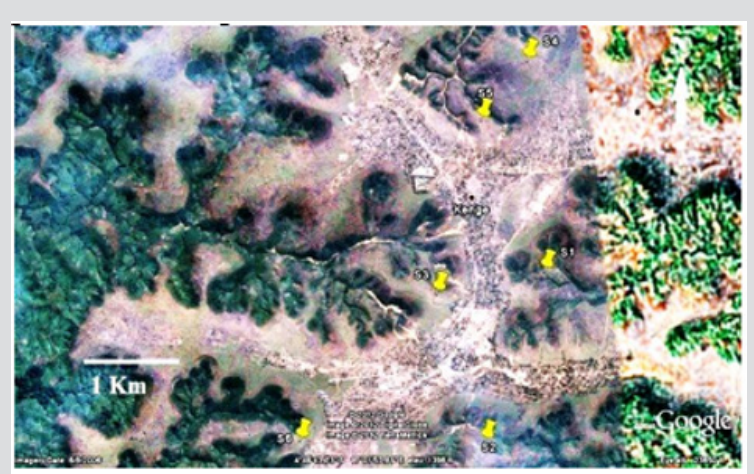

Figure 1: Cartography of hills and valleys of the City of Kenge.

A majority of the population of Kenge (80\%) is rural and agropastoralist. Trading also offers income and employment in terms of small and medium businesses, motorcycle taxis. The remainder of the population is employed in the education, health and public administration sectors. This population is essentially from the Yaka ethnic group but can be cosmopolitan in urban areas. The latter includes populations from other ethnic groups such as Hungani, Kongo, Lonzo, Luba, Mbala, Pelende, Ngala, Suku, Swahili and others. The Pelende tribe (from Yaka ethnic group) is the most dominant tribe in the city of Kenge. To curb chronic undernutrition among these people and boosts child cognitive development, learning skills, academic performance and adult productivity, there is an urgent need for changing the way natural resources are being managed and used in this health zone. There is also need for a possible commitment of all stakeholders in the planning and management of these resources. That is why this study provides a quick appraisal, which aims to set the stage for a deep inquiry for participatory natural resources management.

\section{Data Collection and Analysis}

This study mainly banks on a triangulation of data from a desk review and a direct observation of the Kenge ecosystem. It uses data from a random sample of 5 categories of traditional food used in the Kenge Health Zone. The analysis is based on typical ecosystem services' valuation in the agriculture, food and nutrition. It demonstrates the biochemical composition of some foodstuffs that are eroded by deforestation and thus resulting in some significant effects on food security, human nutrition and health.

\section{Results and Discussion}

Tables 1 to 5 present the bio-chemical composition of some traditional foodstuffs randomly be selected in the Kwango province, which include edible caterpillars and insects, fish and wild meat, 
edible mushrooms, nutritious roots and tubers, as well as some nutritious fruits, nuts and grains. Table 1 present the bio-chemical composition of some edible caterpillars and insects randomly selected. It shows that most caterpillars are rich in proteins which contents range from 10 to $20 \%$ per $100 \mathrm{~g}$ of comestible matter. When dried up the contents may sky up above $50 \%$ per $100 \mathrm{mg}$ of dried matter. Thus, the use of caterpillar flour has been acknowledged as a significant contributor to the nutrition of the under 5-year olds. Most of these caterpillars live in thickets and woody savannas which have been destroyed through deforestation for various reasons: agriculture, charcoal and timber production. The destruction of Table 1: Edible caterpillars and insects randomly selected in Kwango [1]

\begin{tabular}{|c|c|c|c|c|c|c|c|c|c|}
\hline $\mathbf{N}^{\circ}$ & Local name & Scientific Name & Calories (Kcal) & Proteins (g) & Lipids (g) & Carbo-hydrate (g) & Ca (g) & $\mathrm{Fe}(\mathrm{g})$ & P (mg) \\
\hline 1 & Maningu & $\begin{array}{l}\text { Brachytrupes } \\
\text { membranaceus }\end{array}$ & 262 & 15.57 & 21.06 & 2.56 & 50.10 & 0.99 & 126.14 \\
\hline 2 & Mikwati & Cirina forda & 81 & 13.09 & 1.86 & 3.07 & 152.97 & 0.22 & 561.59 \\
\hline 3 & Mikoko & Ela phodes latea & 470 & 68.06 & 16.77 & 17.73 & 370.08 & (1.17) & \\
\hline 4 & Mangengeni & Termes spp & 355 & 36.76 & 28.00 & 4.2 & & & \\
\hline 5 & Mindanda & & 205 & 16.29 & 7.11 & 18.9 & 308.07 & & 654.54 \\
\hline 6 & Mifugungu & & 459 & 52.06 & 20.95 & 15.6 & 119.64 & 3.06 & 389.14 \\
\hline 7 & Madidi & & 395 & 73.36 & 3.03 & 18.03 & 139 & & 355.59 \\
\hline 8 & Ebob & & & 27.74 & 3.17 & 9.8 & 285.09 & & \\
\hline 9 & Bakambuti & & 179 & 26.77 & & - & 40.87 & & 305.57 \\
\hline 10 & Bakatseya & & 163 & 27.38 & 2.63 & 7.41 & & & 189.22 \\
\hline
\end{tabular}

Note :

1 Units per $100 \mathrm{mg}$ of comestible matter.

Table 2: Fish and wild meat randomly selected in Kwango1.

\begin{tabular}{|c|c|c|c|c|c|c|c|c|c|}
\hline $\mathbf{N}^{\circ}$ & Local name & Scientific Name & Calories (Kcal) & Proteins (g) & Lipids (g) & Carbo-hydrate (g) & $\mathrm{Ca}(\mathrm{g})$ & $\mathrm{Fe}(\mathrm{g})$ & $P(\mathrm{mg})$ \\
\hline 1 & Misombi & $\begin{array}{l}\text { Chanmellabes } \\
\text { tupus }\end{array}$ & 339 & 65.89 & 8.34 & - & 2937.16 & & \\
\hline 2 & Mayanga & $\begin{array}{l}\text { Citharinus } \\
\text { gubbosus sp. }\end{array}$ & 331 & 72.20 & 4.64 & - & 3199.43 & 947.46 & \\
\hline 3 & Muengi & $\begin{array}{c}\text { Claracidae } \\
\text { hydrocyon goliath }\end{array}$ & 314 & 67.09 & 5.04 & - & 3001.31 & 607.92 & \\
\hline 4 & Ngolo & Clarias angolensis & 318 & 62.52 & 7.59 & - & 3062.57 & 963.48 & \\
\hline 5 & Mombete & $\begin{array}{l}\text { Cypriridae labeo } \\
\text { waksii }\end{array}$ & 325 & 72.21 & 4.00 & - & 2999.44 & 876.99 & \\
\hline 6 & Mbongo & $\begin{array}{c}\text { Mormyridae } \\
\text { gnathonemus } \\
\text { munteiri }\end{array}$ & 345 & 72.37 & 6.16 & - & 3546.9 & 901.79 & \\
\hline 7 & Mungusu & $\begin{array}{c}\text { Parachana } \\
\text { obscura }\end{array}$ & 346 & 80.14 & 2.85 & - & 2300.79 & & \\
\hline 8 & Ngondo & $\begin{array}{c}\text { Crocodylus } \\
\text { osteolaemus sp. }\end{array}$ & 346 & 63.18 & 10.36 & - & & & 452.43 \\
\hline 9 & Nkumbi & $\begin{array}{l}\text { Crycetomes } \\
\text { gambiansis }\end{array}$ & 85 & 20.04 & 0.59 & - & 998 & 14.01 & 85.62 \\
\hline 10 & Mwebu & & 77 & 64.95 & 5.74 & - & 1516.29 & 0.31 & 90.81 \\
\hline
\end{tabular}

Note :

1 Units per $100 \mathrm{mg}$ of comestible matter. 
Most of the small animals and reptiles listed above live in bushland and cleared forests in while fishes are naturally found in freshwater ecosystems like rivers, lakes, marshlands and mangroves. However, the high rate of deforestation along with soil erosion have led to the depletion of these natural foodstuffs, thus constraining rural poor people to buy expensive meat and fish from cities or other locations. These are some of the factors that have boosted undernutrition in the Kwango province. There is an urgent need for protecting biological species that serve for food through ecological conservation. Table 3 shows some edible mushrooms randomly selected in the Kwango province. Traditional societies substituted mushrooms to vegetables and/ or animal proteins, which helped them to keep a balanced diet and remain healthy both physically and emotionally. These food items were found both in the savan- na and forest. Unfortunately, these ecosystems are being destroyed through anthropogenic activities. The latter have had an impact on the spread of desertification and malnourishment in the Kwango province. There is thus a need for ecological conservation. Besides proteins, most indigenous populations get their food energy and vitamins from roots and tubers (Table 4). In fact, more than 20 roots and tubers are recorded in the Kwango province. Even though these foodstuffs are poor in proteins, they are rich in calories (above 300 $\mathrm{Kcal} / 100 \mathrm{mg}$ ), vitamins and mineral salts. Their flour is being used as porridge for feeding children under the age of 5years and pregnant women and mothers suffering from kwashiorkor. Research has shown that the consumption of arrow root flour controls the concentration of glucose and insulin in the blood of the children, thus preventing the child from high glycaemia and diabetes.

Table 3: Edible mushrooms randomly selected in Kwango1.

\begin{tabular}{|c|c|c|c|c|c|c|c|c|c|}
\hline $\mathbf{N}^{\circ}$ & Local name & Scientific Name & Calories (Kcal) & Proteins (g) & Lipids (g) & Carbo-hydrate (g) & Ca (g) & $\mathrm{Fe}(\mathrm{g})$ & $P(\mathrm{mg})$ \\
\hline 1 & Bututulu & Cantharellis sp. & 35 & 4.6 & 0.24 & 4.36 & 4.95 & & 20.49 \\
\hline 2 & Makopa & Cockeina Subcipes & 73 & 5.89 & 0.31 & 14.56 & & & \\
\hline 3 & Butseyila & Lentinus sp. & 56 & 4.58 & 0.25 & 9.74 & & & \\
\hline 4 & Butondi & $\begin{array}{l}\text { Pleurotus } \\
\text { tebernegium }\end{array}$ & 119 & 6.22 & 0.15 & 24.10 & 11.8 & & \\
\hline 5 & $\begin{array}{l}\text { Kimasi- } \\
\text { masi }\end{array}$ & $\begin{array}{l}\text { Pluteolus } \\
\text { acuminata }\end{array}$ & 92 & 6.29 & 0.45 & 17.01 & & & \\
\hline 6 & Bukolokoto & $\begin{array}{l}\text { Schizophyllum } \\
\text { commune }\end{array}$ & 133 & 5.52 & 0.49 & 27.82 & 24.55 & & \\
\hline 7 & Bupalanga & Termitomyces sp & 363 & 31.58 & 3.60 & 57.59 & & & \\
\hline 8 & $\begin{array}{l}\text { Nsudi-ya- } \\
\text { Babakala }\end{array}$ & $\begin{array}{c}\text { Tricholomataceae } \\
\text { sp. }\end{array}$ & 373 & 34.56 & 6.23 & 50.92 & & & \\
\hline 9 & Buniengeni & & 41 & 4.25 & 0.17 & 6.58 & 6.24 & 0.02 & \\
\hline 10 & $\begin{array}{l}\text { Dimi-di- } \\
\text { mbwa }\end{array}$ & & 52 & 5.10 & 0.65 & 7.43 & & & \\
\hline
\end{tabular}

Note :

1 Units per $100 \mathrm{mg}$ of comestible matter.

Table 4: Nutritious roots and tubers randomly selected in Kwango 1

\begin{tabular}{|c|c|c|c|c|c|c|c|c|c|}
\hline $\mathbf{N}^{\circ}$ & Local name & Scientific Name & Calories (Kcal) & Proteins (g) & Lipids (g) & Carbo-hydrate (g) & $\mathrm{Ca}(\mathrm{g})$ & $\mathrm{Fe}(\mathrm{g})$ & P (mg) \\
\hline 1 & Langa & $\begin{array}{l}\text { Colacasia esculanta } \\
\text { (Araceae) }\end{array}$ & 131 & 2.45 & 0.45 & 29.98 & 16.76 & & 6.36 \\
\hline 2 & Muasa & $\begin{array}{l}\text { Cucurma Longa } \\
\text { (zingiberaceae) }\end{array}$ & 89 & 1.9 & 0.33 & 20.47 & 33.14 & & \\
\hline 3 & Bateku & $\begin{array}{c}\text { Dioscorea } \\
\text { Bubbifera } \\
\text { (Dioscoreaceae) }\end{array}$ & 90 & 2.0 & 0.16 & 20.62 & 20.62 & 0.01 & \\
\hline 4 & Mboma & $\begin{array}{c}\text { Dioscorea } \\
\text { Bubbifera } \\
\text { (Dioscoreaceae) }\end{array}$ & 148 & 2.0 & 0.24 & 35.27 & 9.45 & & \\
\hline 5 & $\begin{array}{l}\text { N'lembu- } \\
\text { N'lembu }\end{array}$ & $\begin{array}{c}\text { Dioscorea } \\
\text { Bubbifera } \\
\text { (Dioscoreaceae) }\end{array}$ & 107 & 3.5 & 0.45 & 22.75 & 31.87 & & 9.23 \\
\hline 6 & Kengi-Kiashi & $\begin{array}{c}\text { Pentadilapandra } \\
\text { Brazzera }\end{array}$ & & 1.5 & 0.17 & - & & & \\
\hline 7 & Mfuyu & $\begin{array}{l}\text { Sphenostylis } \\
\text { stenocarpa } \\
\text { (Farbaceae) }\end{array}$ & 52 & 1.75 & 0.1 & 11.22 & 12.63 & & 18.93 \\
\hline
\end{tabular}




\begin{tabular}{|c|c|c|c|c|c|c|c|c|}
\hline 8 & Kamenge & $\begin{array}{c}\text { Sorghum } \\
\text { arundinacum }\end{array}$ & 102 & 3.64 & 56.01 & 21.56 & 115.04 & \\
\hline 9 & Kikanzu & Sorghum bocolor & 99 & 1.65 & 0.4 & 22.91 \\
\hline 10 & Kimbiolongo & & 136 & 3.46 & 1.29 & 31.45 & 358.45 & 35.85 \\
\hline
\end{tabular}

Note :

1 Units per $100 \mathrm{mg}$ of comestible matter.

Other studies have shown that mothers consuming approximately $400 \mathrm{mg}$ of arrow roots per day during 30 days had less total blood cholesterol, oxidative stress and blood pressure, owing to the effects of diosgenina and discorina as well phenolic components of these roots. Another example is that of discorea roots, which particularly have amylolitic activity that increases throughout plant growth and contributes to the improvement of energy density in food supplement. This constitutes a remedy to viscosity issues in child feeding. Finally, Table 5 shows some randomly selected fruits, nuts and grains species in the province. They are among ingredients found in the diets of most indigenous populations in the Kwango province. About 30 fruits consumed in Kwango have been recorded by scientists, some being rich in protein (10\% and above) and others in fat (40\% and above). Among fat acids consumed in the Kwango province, some are essential oils (like linoleic and linolenic acids) and other peanut based acids, such as Omega 3 and 6 oils found in groundnuts (Bendit, 2004). Just like hormones, the latter capture proteins to enable biochemical effects to occur locally. Pumpkins (curcubita sp) contain a lot of beta carotenes and are a great source of vitamin A for the body (Aguilar et al., 2002). They also lutein and zeaxanthina, some antioxidants that improve the defensive functioning of cells against free radicals, especially around retina and macula of our eyes, thus preventing us from some forms of blindness, cardiovascular disease and cancers such as lung and breast cancers (Bone 1988). Besides, pumpkin juice may protect people against some forms of diabetes by reducing sugar in the blood. Finally, these lipids bring a lot of energy to the body, some being above $500 \mathrm{kcal}$ per $100 \mathrm{mg}$ (Bhutt et al., 2008).

\section{Conclusion and Recommendations}

\section{Conclusion}

The Democratic Republic of Congo (DRC) has undergone several structural changes in social behaviors, economics and health due to the burden of wars and the changing natural environment. Long known as the equatorial forest and food basket of the central African region, the country has been the theatre of wars and deforestation, which have affected the livelihoods of the people and led to incredible environmental degradation over the last 40 years. This situation has paralyzed policy-making in the field of food security and nutrition, because of the many unanticipated challenges they encounter on the ground when implementing national strategies. If some challenges are economic and social by nature, others are climatic and environmental. The Province of Kwango in general and the Kenge health zone in particular are facing the same challenges. So what can be done to ensure sustainable solutions the thorny issues of endemic undernutrition among the under 5-year olds, notwithstanding the economic burden of high food prices and low incomes in rural and peri-uban areas of this health zone? This study provides scientific information that highlights the importance of traditional food in the nutrition and health of communities living in Province of Kwango. It is gives a quick appraisal of the effects of environmental degradation on nutrition in order to set the stage for a deep inquiry for participatory natural resources management. It demonstrates how the biochemical composition of some foodstuffs are eroded by deforestation and thus resulting in some significant effects on food security, human nutrition and health. It thus emphasizes the need for protecting ecosystems that are the food baskets of these communities against deforestation and soil erosion. By doing so, policymakers may increase food security and protect children and their mothers against undernutrition in the Province of Kwango in general and the Kenge health zone in particular.

\section{Recommendations for Further Studies}

Economists have long neglected to include the degradation of environmental resources in their national accounts. Yet, deforestation, soil erosion and pollution have direct effects on the scarcity of natural resources, which threaten human health and welfare and therefore the sustained productivity of the economy. The UN has provided a framework that mostly uses data and indicators for the measurement of the long-term sustainable economic growth and development, and social welfare based on environmental trends and performance. In the present study, the researcher attempts to implement the UN System of EnvironmentalEconomic Accounting (SEEA) to reflect environmental concerns in the accounting framework of economic growth based on the nutritional counterpart of health and social welfare (UN, 2012; 1990; Bartelmus et al., 1991). It is therefore crucial to develop an analytical framework that will incorporate climatic and hydrogeomorphological change metrics into the UN SEEA to measure the economic costs of environmental degradation with subsequent impact on undernutrition. This accounting framework may be used as a "Satellite" system for an integrated SEEA Central Framework (CF), which comprises flow accounts and balance sheets for the environmental costs of economic activities and the relevant natural assets and expenditures needed for environmental protection and enhancement. Such accounting system will enable the computation of the following adjusted indicators: 
a) The cost of the depletion of natural resources

b) The expenditure for the replacement of traditional food by alien foodstuffs

c) The income and product, capital and value added that will permit ecological activities for environmental rehabilitation to allow indigenous communities to keep a balanced diet and quality nutrition in response to the effects of the depletion of natural resources.

To assess the depletion of natural resources, a remote sensed study will be conducted based on Landsat satellite images of the Kwango province of DRC ranging from 1976 to 2016. The resulting dynamics of land use and land-cover change (LULCC) will be translated into environmental depletion intensity (Edi) and natural resource abuse (nRa) to account for the loss of traditional food stock. Then, the SEEA-CF will be used to include household access to natural resources that are directly linked to environmental pressures and impacts on chronic undernutrition around the
Kenge Municipality. This framework will permit the costing of the investment needed for conducting ecological rehabilitation activities in order to address the long-term trend in food depletion and endemic malnourishment. To clarify the proposed approach, the study will randomly sample 5 categories of traditional food to demonstrate the quantitative effects of the deforestation and environmental degradation on food security and human nutrition and health. Tables 1-5 present the biochemical composition of some foodstuffs, which will randomly be selected in the Kwango province. Finally, the study will extend the analysis to Contingent Valuation (CV) methods to evaluate an econometric utility function for the people's Willingness to Buy-In (WTB) ecological conservation. These indicators will finally be aggregated to estimate the amount of income and product that would accrue from ecological conservation to reverse environmental degradation. The success of the measurements from the Kenge health zone may be up/out scaled to study other rural African regions and serve as a basis for shaping nutrition focused policy in the course of climate change.

Table 5: Nutritious fruits, nuts and grains randomly selected in Kwango 1.

\begin{tabular}{|c|c|c|c|c|c|c|c|c|c|}
\hline $\mathbf{N}^{\circ}$ & Local name & Scientific Name & Calories (Kcal) & Proteins (g) & Lipids (g) & Carbo-hydrate (g) & Ca (g) & $\mathrm{Fe}(\mathrm{g})$ & $P(\mathrm{mg})$ \\
\hline 1 & Tundu & $\begin{array}{l}\text { Afromomum sp } \\
\text { (zingiberaceae) }\end{array}$ & 118 & 1.99 & 1.58 & 25.63 & & & \\
\hline 2 & Tundu-zi-Nseke & $\begin{array}{l}\text { Afromomum sp } \\
\text { (Melegueta) }\end{array}$ & 103 & 3.42 & 3.64 & 29.77 & & & \\
\hline 3 & Mfungu & $\begin{array}{l}\text { Anisophyllea quangensis } \\
\text { (Rizophoraceae) }\end{array}$ & & 1.46 & 1.48 & 21.83 & & & \\
\hline 4 & Nguba mputu & $\begin{array}{l}\text { Bombascopsis glabra } \\
\text { (Bombacaceae) }\end{array}$ & 552 & 15.1 & 44.9 & 31.20 & & & \\
\hline 5 & Mbidi & $\begin{array}{l}\text { Cararium schweimfurthii } \\
\text { (Burseraceae) }\end{array}$ & 202 & 4 & 10.37 & 31.58 & & & \\
\hline 6 & Dibamvu & $\begin{array}{l}\text { Chryphylum la courtianum } \\
\text { (Sapotaceae) }\end{array}$ & & 1.27 & 1.7 & - & & & \\
\hline 7 & Makasu & $\begin{array}{l}\text { Cola acuminata } \\
\text { (sterculiaceae) }\end{array}$ & 163 & 1.97 & 0.43 & 39.62 & & & \\
\hline 8 & Maleenga & $\begin{array}{l}\text { Cucurbita maxima sp } \\
\text { (cucurbitaceae) }\end{array}$ & 622 & 27.6 & 56.01 & 5.61 & & & \\
\hline 9 & Mpeya & $\begin{array}{c}\text { Monodora Myristica } \\
\text { (Annonaceae) }\end{array}$ & 518 & 12.7 & 42.8 & 30.23 & & & \\
\hline 10 & Maracuja & Passiflora edulis & 62 & 0.96 & 1.17 & 12.13 & & & \\
\hline
\end{tabular}

Note :

1 Units per $100 \mathrm{mg}$ of comestible matter.

\section{References}

1. Aguilar AFJ, Galacia HE, Campos-Sepulveda AE, Xolalpa-Molina S, RivasVilchis JF, et al. (2002) Evaluation of the hypoglycemic effect of Cucurbita Ficifolia Bouche (Cucurbitaceae) in different experimental models. Journal of Ethnopharmacology 82(2-3): 185-189.

2. (2006) AMCW, AfDB, EUWI, World Bank-WSP and UNDP (eds). Getting Africa on Track to Meet the MDGs on Water Supply and Sanitation - A Status Overview of Sixteen African Countries. Nairobi.

3. Bendit A (2004) From 1989 to 2001: what have we learned about the "biological actions of beta-carotene". Journal of nutrition 134 (1): 225S-230S
4. Bhutt ZA, Ahmad T, Black RE (2008) For maternal and child undernutrition study group. What works? Interventions for maternal and child undernutrition and survival.

5. Bone RA, Landru JT (1988) The analysis of macular pigment by HPLC: retinal distribution and age study. Invest Ophthalmol Vis Sci 29 (6): 843849.

6. Bartelmus P, Stahmer C, Van Tongeren J (1991) Integrated environmental and economic accounting: Framework for a SNA satellite system. Review of Income and Wealth Series 37(2): 111-148.

7. Di Luyundi TM (2013) Aliments et denrées alimentaires traditionels du Bandundu en R.D. Congo - Repertoire et composition en nutriments. Paris: L'Harmattan RDC. 
8. Gond V Dubiez E, Boulogne M, Gigaud M, Peroches A, Pennec A, et al (2016) Focus on forest cover and carbon stock changes in DRC. Bois et forêts des tropiques $n^{\circ} 327(1)$

9. Jansky L, Haigh M, Prasad H (2005) Sustainable Management of Headwater Resources: Researches from Africa and India. In Jansky L, Haigh M, Prasad H (eds). Tokyo: United Nations University Press.

10. Kapende JK (2017) Les Déterminants de la Malnutrition Chronique aux enfants de 0 à 59 mois dans la Province du Kwango. Analyse des Données EDS RDC 2013-2014. Master's Thesis. Kenge: Department of Nutrition and Dietetics, ISTM-MRP de Kenge.

11. Lewis J (2013) Why Didn't All the Aid Reach the Poorest? Here's Why DRC Relief Programme Does Not Work as Expected.

12. Lodi O, Mbemba F, Yandju MC (2011) Détermination de la nature des protéines de feuilles de Gnetum Africanum Welw par spectrophotometrie. Revue Congolaise des Sciences nucléaires pp. 25.

13. Luwesi CN (2018) How the changing environmental trends leads to food shortage and chronic undernutrition in Kenge Municipality, DRC. Proposal submitted to The Friedman School of Nutrition at Tufts University, USA and the London School of Hygiene \& Tropical Medicine, UK.

14. Luwesi CN, Obando JA, Shisanya CA (2017) The impact of a warming micro-climate on Muooni farmers of Kenya. Agriculture 7(3): 1-20.

15. Luwesi CN, Dzigbodi DA, Morrow D (2016) "Solar Geoengineering: Technology-Based Climate Mitigation or Compromising with Social Justice in Africa?" In: Christopher J. Preston (Eds.), Climate Justice and Geoengineering, Chapter 11. New York, NY: Rowman \& Littlefield International, pp. 161-173.

16. Luwesi CN, Shisanya CA, Obando JA (2011) "Toward a hydro-economic approach for risk assessment and mitigation planning for farming water

\section{ISSN: 2574-1241}

DOI: 10.26717/BJSTR.2019.18.003145

Cush Ngonzo Luwesi. Biomed J Sci \& Tech Res

This work is licensed under Creative

Commons Attribution 4.0 License

Submission Link: https://biomedres.us/submit-manuscript.php disasters in semi-arid Kenya". In: M. Savino (eds.), Risk Management in Environment, Production and Economy, InTech, 51000 Rijeka, Croatia pp. 27-46.

17. Majaliwa GM (2008) Land use and climate change effects on livelihoods and sediment and carbon loading in the Lake Tanganyika region. End of project technical report submitted to START.

18. Ngonzo CL, Shisanya CA, Obando JA (2010) Land use and water demand under a Changing Climate: Experiences of Smallholder Farmers from Muooni. In SP Saikia (eds.), Climate Change, International Book Distributors, Jorhat 785 006, India pp. 117-140.

19. Pachauri RK (2004) Climate and humanity. Global Environment Change 14: 101-103.

20. (2014) RDC, République Démocratique Du Congo Deuxième Enquête Démographique et de Santé. Kinshasa: MINISANTE.

21. Parent G (1977) Food value of edible mushrooms from upper Shaba Region (DRC). Economic Botany, 31(4): 436.

22. (2010) UNDP Human Development Report 2010-20 ${ }^{\text {th }}$ Anniversary, The Real Wealth of Nations: Pathways to Human Development. Palgrave Macmillan, New York, USA.

23. Thorton PK, Jones PG, Owiyo T, Kruska RL, Herrero M, et al. (2006) Mapping climate variability and poverty in Africa. Report to the Department for International Development, DFID. Nairobi, ILRI pp. 171

24. (2011) UNEP Water Issues in the Democratic Republic of the CongoChallenges and Opportunities. Technical Report. Nairobi : United Nations Environment Programme (UNEP).

25. Von Braun J, Rosegrant, MW, Pandya Lorch R, Cohen MJ, Cline SA, et al. (2005) New Risks and Opportunities for Food Security Scenario Analyses for 2015 and 2050. IFPRI Policy Brief pp. 73.

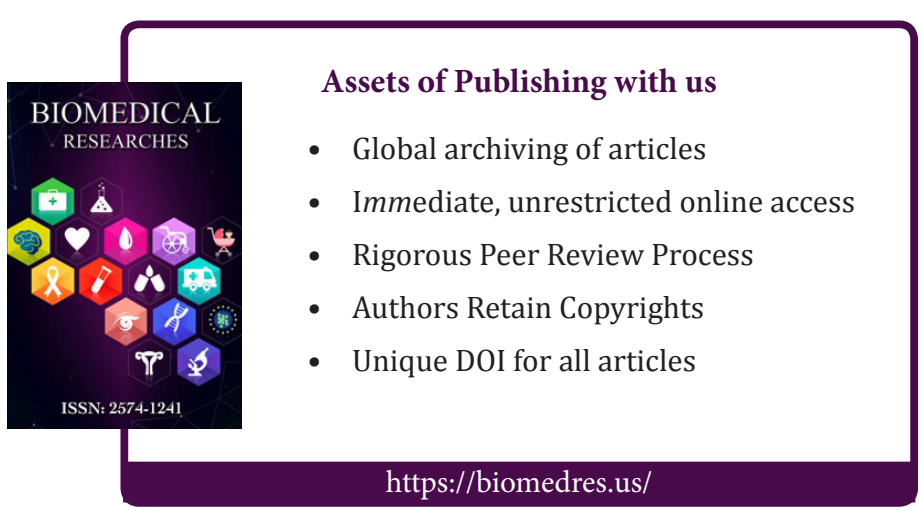

